\title{
Isolation, characterization and identification of endophytic bacteria in sugarcane (Saccharum spp. L.) cultivated on soils of the Dong Nai province, Southeast of Vietnam
}

\author{
Hoang Minh Tam ${ }^{1, *}$, Cao Ngoc Diep ${ }^{2}$ \\ ${ }^{1}$ Dept. Natural Science Teacher Training, Sai Gon University, HCM City, Vietnam \\ ${ }^{2}$ Dept. Microbiology Biotechnology, Biotechnology R\&D Institute, Can Tho University, Can Tho City, Vietnam
}

Email address:

hoangminhtam18@yahoo.com (H. M. Tam), cndiep@ctu.edu.vn (C. N. Diep)

\section{To cite this article:}

Hoang Minh Tam, Cao Ngoc Diep. Isolation, Characterization and Identification of Endophytic Bacteria in Sugarcane (Saccharum spp. L.) Cultivated on Soils of the Dong Nai Province, Southeast of Vietnam. American Journal of Life Sciences. Vol. 2, No. 6, 2014 , pp. $361-368$. doi: 10.11648/j.ajls.20140206.16

\begin{abstract}
Endophytic bacterial diversity in sugarcane plant cultivated on Latosols and Acrisols of the Eastern of South Vietnam was studied. Sugarcane plant samples were taken in four sites (districts/towns) (Xuanloc, Dinhquan, Vinhc uu and Trangbom) of Dong Nai province. Endophytic bacteria were isolated in LGI medium together with 16S rRNA gene fragments amplified from DNA using eubacterial universal primers (p515FPL and p13B). A total of 27 isolates were isolated on LGI medium and all of them have ability of nitrogen fixation and phosphate solubilization together with IAA biosynthesis but there were 10 isolates having the best characteristics. The sequences from selected endophytic bacteria (10 isolates) showed high degrees of similarity to those of the GenBank references strains (between 98\% and 99\%). All of them are Proteobacteria (gram-negative bacteria) and 3 isolates belonged to Alpha-proteobacteria (30\%), 2 isolates were Beta-proteobacteria (20\%), 5 isolates were Gamma-proteobacteria (50\%). Based on Pi value (nucleotide diversity), Gamma-proteobacteria group had the highest theta values and Theta values (per sequence) from S of SNP for DNA polymorphism were calculated for each group and Gamma-proteobacteria group had the highest values in comparison of two groups. From these results showed that Enterobacter oryzae LT7, Achromobacter xylosoxidans T16, Achromobacter insolitus R15b and Pantoea agglomerans T12 revealed promising candidates with multiple beneficial characteristics and they have the potential for application as inoculants or bio-fertilizer adapted to poor latosols and acrisols because they are not only famous strains but also are safety strains for sustainable agriculture.
\end{abstract}

Keywords: Acrisols, 16S rRNA Gene Sequence, Latosols, the Eastern of the South Vietnam, Endophytic Bacteria, Sugarcane

\section{Introduction}

Sugarcane (Saccharum spp.) is a tropical and sub-tropical crop that can produce sugars and a large amount of chemical fertilizers have been applied to sugarcane to promote early growth in many countries, especially in developing countries [1]. In this sustainable sugarcane production, biological nitrogen fixation (BNF) has replaced chemical fertilizers [2][3]. There have been long-term search efforts to identify the $\mathrm{N}_{2}$-fixing bacteria involved in sugarcane production [4]. Cavalcante and Dobereiner [5] first isolated endophytic $\mathrm{N}_{2}$ fixing bacteria from sugar juice and gave this bacterium its species name, Acetobacter diazotrophicus (now
Gluconacetobacter diazotrophicus). Subsequently, several endophytic N2-fixing bacteria, such as Herbaspirillum sp. [6], Pantoea sp. [7], Burkholderia tropica [8], B. unamae [9]. and $B$. silvatlantica [10], were isolated from sugarcane plants. Endophytes represent a subgroup of the rhizobacterial communities that have the ability to enter the roots of their hosts after the rhizoplane is colonised [11]. Endophytic bacteria colonise the intercellular spaces and the inside of xylem vessels and may promote plant growth directly or indirectly [12][13].

The Southeast of Vietnam locates from 105o49' to 107o35' $\mathrm{E}$ and from $10 \mathrm{o} 20^{\prime}$ to $12 \mathrm{o} 17^{\prime} \mathrm{N}$, it is one of the two regions of South Vietnam situated in the east of part of South Vietnam, covering 2.34 millions ha, occupied approximately 
$20.3 \%$ of total of Vietnam area. The soils are mainly red latosols (from origin of volcanic mountain) and acrisols with a $\mathrm{pH}$ range of $4.5-5.0$. They are considered nutrient poor, with an average organic matter of $2 \%$, a total nitrogen range of $0.14-0.19 \%$, and a very low available phosphorus, cation exchange capacity, exchangeable $\mathrm{K}$ and contain more sand in their structure [14]. The Southeast of Vietnam and the Mekong Delta (Southwest) are two big sugarcane cultivation regions in the South Vietnam; the sugarcane area occupied $12.7 \%$ with 34,395 ha, the production and productivity were 66.5 ton/ha and productivity was $2,329,435$ tons, respectively [ 15 ] . It has been a general practice to apply $250 \mathrm{~kg} \mathrm{~N}$ ha-1 yr-1 or more in most sugarcane cultivating countries [16] as in sugarcane fields in Spain farmers frequently use high amounts of fertilizers (400-500 kg N ha-1 yr-1). Interactions and association between microorganism and their host plants may be inhibited by high levels of added fertilizer [17] and many of these bacteria are beneficial to their hosts, and are collectively termed plant growth-promoting rhizobacteria (PGPR). Recent interest has focused particularly upon PGPR that are endophytic (i.e. PGPE), are which have been reported to be associated with important crops such as rice, wheat and sugarcane [18].

In the present work we report characterization of endophytic bacteria isolates from sugarcane plants collected from four agricultural soils (Xuanloc, Trangbom, Vinhcuu and Dinhquan district) in Dong Nai province which is one in two important sugarcane cultivating regions of southeast of Vietnam.

\section{Materials and Methods}

\subsection{Sample Collection and Isolation of Endophytes}

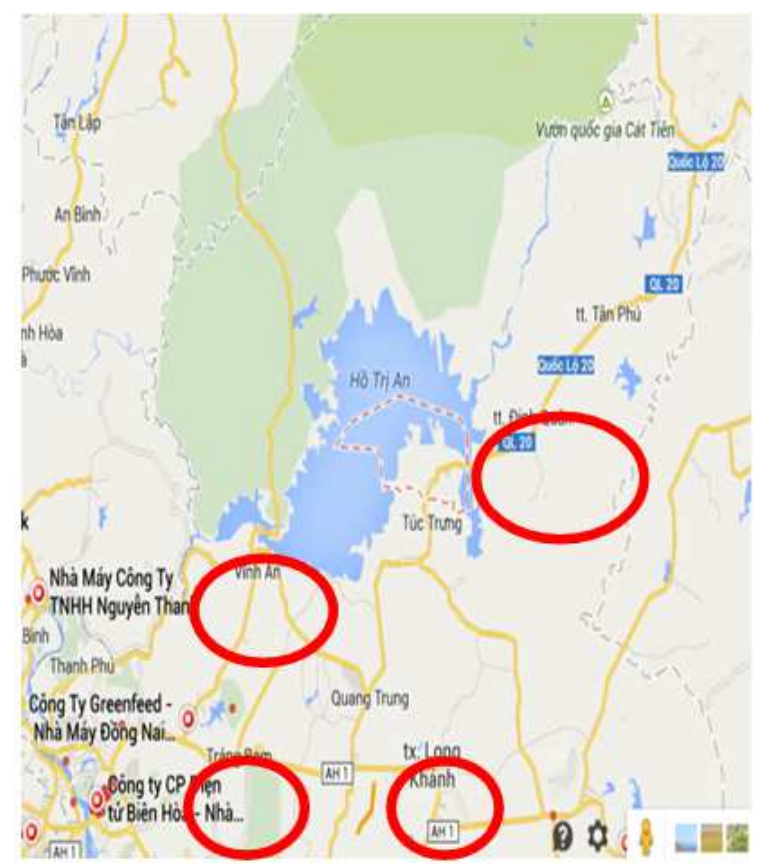

Figure 1. The geographic map and the locations of southeast of Vietnam examined in this study and sugarcane samples were collected at the these sites (Xuanloc, Trangbom, Vinhcuu and Dinhquan) of Dong Nai province
Four sugarcane fields (Xuanloc, Vinhcuu, Trangbom and Dinhquan) in Dong Nai province were sampled. Fields have been in monoculture for more than five years and sugarcane plants were fertilized with different levels (from 200-500 kg N ha ${ }^{-1} \mathrm{yr}^{-1}$ ). Sugarcane plants were collected at four sites of Dongnai province (Figure 1).

Samples were obtained whole plant after that soil rhizosphere was separated for further experiments, collected the whole plant after that roots and stems $(50-\mathrm{cm})$ of sugarcane plant [hybrid variety](near 6 months old plant) were collected, stem were washed with tap water to remove attached clay. Subsequently, the stems were immersed in $70 \%$ ethanol in $3 \mathrm{~min}$, washed with fresh sodium hypochlorite solution ( $2.5 \%$ available CT) for $5 \mathrm{~min}$, rinsed with $70 \%$ ethanol for $30 \mathrm{~s}$ and finally washed five times with sterile distilled water. To confirm that the sterilization process was successful, the aliquots of the sterile distilled water used in the final rinse were set on tryptic soy agar (TSA) medium plates. The plates were examined for bacterial growth after incubation at $28^{\circ} \mathrm{C}$ for 3 days. Sugarcane stem and roots samples that were not contaminated as detected by culture-dependent sterility test were used for further analysis.

Samples were cut to $0.5-\mathrm{cm}$ pieces and macerated with a sterile mortar and pestle; tissue extracts were then serially (tenfold dilution) in sterile water, $200 \mu$ l-aliquot samples were used to inoculate in (in triplicate) Nitrogen-free semisolid LGI in $5 \mathrm{ml}$ tubes. After 48-72 $\mathrm{h}$ incubation, bacteria growing in tubes as a white or yellow pellicle at a depth of 1 to $4 \mathrm{~mm}$ were streaked on LGI agar plates, cultures were streaked on media to obtain single colonies. Bacterial colonies were differentiated on the basis of colony morphology and pigmentation. Colonies were subculture on the agar-based subculture medium plates by striking technique and re-incubated at $30^{\circ} \mathrm{C}$ for 4 days. This isolation process carries out in shifts of the agar-based culture medium to the agar-based subculture medium until monocultures were obtained. Monocultures were culture on the agar-based culture medium slant in the test-tube $(12 \mathrm{ml})$ and incubated at $30{ }^{\circ} \mathrm{C}$ for 4 days following by stored $10{ }^{\circ} \mathrm{C}$ in refrigerator.

\subsection{Culture Media and Growth Condition}

Isolation media was LGI [5]; for biofertilizer activities were Burk'N free [19], NBRIP [20].

\subsection{Colony Characteristic and Microscopic Examination}

The characteristics of colony such as size, color, shape....were presented in each group, cell morphologies of the isolates were observed using an optical microscope and they were also observed on scanning electron microscope.

\subsection{Screening for Biofertilizer Activities}

The ability to fix $\mathrm{N}_{2}$ was tested on Burk'N-free liquid medium incubating at $30^{\circ} \mathrm{C}$ and the ammonium concentration in medium was measured by Phenol Nitroprusside method after 2,4,6 and 8 day inoculation (DAI) 
and inorganic phosphate solubilization ability was tested on NBRIP liquid medium and they were incubated at $30^{\circ} \mathrm{C}$ and the $\mathrm{P}_{2} \mathrm{O}_{5}$ concentration was measured by ammonium molypdate method. The qualitative detection of indole-3acetic acid (IAA) production was carried out based on the colorimetric method [21]. Precultures were grown in Burk's $\mathrm{N}$ free $(100 \mathrm{ml})$ without tryptophan in $250 \mathrm{~mL}$-flask at $30^{\circ} \mathrm{C}$ on a roller at $100 \mathrm{rpm}$ and samples were taken from at 2, 4, 6 , and $8 \mathrm{DAI}$, cell free supernatants were mixed $2: 1$ with Salkowki reagent $\left(0.01 \mathrm{M} \mathrm{FeCl}_{3}\right.$ in $35 \%$ perchloric acid) and incubated in the dark for $20 \mathrm{~min}$ at RT. IAA-containing solutions were indicated by reddish color with an absorption peak at $530 \mathrm{~nm}$ on Genesys 10uv Thermo Scientific spectrophotometer.

\subsection{S rDNA Gene Amplification and Sequencing}

Bacterial DNA was isolated following published protocols [22]; The following primers were used for PCR amplification of $16 \mathrm{~S}$ ribosomal DNA: p515FPL [23] and p13B [24] [25]. The $50 \mu \mathrm{L}$ reaction mixture consisted of 2.5 U Taq Polymerase (Fermentas), $0.1 \mathrm{mM}$ of each desoxynecleotide triphosphate, $1.5 \mathrm{mM}$ magnesium chloride, $0.4 \mathrm{mM}$ spermidine (Sigma), $10 \mathrm{pM}$ of each primer (Fermentas) and $10 \mathrm{ng}$ DNA, 10\% (vol/vol) dimethyl disulfide (Fermentas). The thermocycling profide was carried out with an initial denaturation at $94^{\circ} \mathrm{C}(3 \mathrm{~min})$ followed by 30 cycles of denaturation at $94^{\circ} \mathrm{C}(60 \mathrm{~s})$, annealing at $57^{\circ} \mathrm{C}(60 \mathrm{~s})$, extension at $72^{\circ} \mathrm{C}(120 \mathrm{~s})$ and a final extension at $72^{\circ} \mathrm{C}(4 \mathrm{~min})$ in $\mathrm{C} 1000$ Thermal Cycler (Bio-Rad). Aliquots $(10 \mu \mathrm{l})$ of $\mathrm{PCR}$ products were electrophoresed and visualized in $1 \%$ agarose gels using standard electrophoresis procedures. Partial 16S rRNA gene of selectived isolates in each site was sequenced by MACROGEN, Republic of Korea (dna.macrogen.com). Finally, 16S rRNA sequence of the isolate was compared with that of other microorganisms by way BLAST (http://www.ncbi.nlm.nih.gov/BLAST/Blast.cgi); In the best isolate(s)(high ability of nitrogen fixation, phosphate solubilization and IAA synthesis) and 27 isolates of 4 sites were chosen to sequence and the results were compared to sequences of GenBank based on partial 16S rRNA sequences to show relationships between endophytic strains [26] and phylogenetic tree were constructed by the neighbor-joining method using the MEGA software version 6.06 based on 1000 bootstraps.

\subsection{SNPs Discovery}

The sequence data from 30 endophytic bacterial isolates were analysed with SeqScape@Software (Applied Biosystem, Foster City, CA, USA). SeqScape is a sequence comparison tool for variant identification, SNP discovery and validation. It considers alignment depth, the base calls in each of the sequences and the associated base quality values. Putative SNPs were accepted as true sequence variants if the quality value exceeded 20 . It means a $1 \%$ chance basecall is incorrect.

\subsection{Nucleotide Diversity $(\theta)$}

Nucleotide diversity $(\Theta)$ was calculated by the method described by Halushka et al. [27].

$$
\Theta=K / a L \quad a=\sum_{i=2}^{n} l /(i-l)
$$

where $\mathrm{K}$ is the number of SNPs identified in an alignment length, $\mathrm{n}$ is alleles and $\mathrm{L}$ is the total length of sequence (bp).

\subsection{Data Analyses}

Data from ammonium, orthophosphate and IAA concentrations in media were analysed in completely randomized design with three replicates and LSD test at $\mathrm{P}=0.01$ were used to differentiate between statistically different means using SPSS version 16.

\section{Results and Discussion}

\subsection{Bacteria Isolation, Colony Characteristic and Microscopic Examination}

The endophytic bacteria developed in the pellicles of semi solid (in LGI medium) as the previous results of Weber et al. [28], Thu Ha et al. [29]. From 14 sugarcane samples of 4 sites (Xuanloc, Trangbom, Vinhcuu and Dinhquan), 27 isolates were isolated on LGI medium (Table 1).

Table 1. Total of isolates were isolated from 4 sites (districts/towns) from roots and stems of sugarcane cultivated on Latosols and Acrisols of Dong Nai province (the eastern of South Vietnam)

\begin{tabular}{|c|c|c|c|c|}
\hline Site & Sample number & Sugarcane sample & Number of isolated isolates & Total \\
\hline \multirow[t]{2}{*}{ Xuanloc } & 3 & Stem & 2 & 5 \\
\hline & & Root & 3 & \\
\hline \multirow[t]{2}{*}{ Trangbom } & 4 & Stem & 5 & 9 \\
\hline & & Root & 4 & \\
\hline \multirow[t]{2}{*}{ Dinhquan } & 4 & Stem & 4 & 9 \\
\hline & & Root & 5 & \\
\hline \multirow[t]{2}{*}{ Vinhcuu } & 3 & Stem & 1 & 4 \\
\hline & & Root & 3 & \\
\hline
\end{tabular}

They developed very well on the LGI medium from 36-48 $\mathrm{h}$ at $30^{\circ} \mathrm{C}$, their colonies had round-shape, climy, smooth, colourless or milk-color, yellow and some colonies appeared to have much larger size (Figure 2). The cells were observed by SEM and appeared as rod and most of them have motility (Figure 3). 

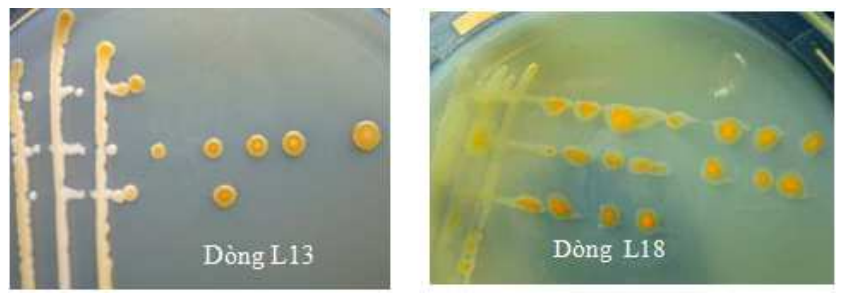

Figure 2. The colonies of several endophyte isolates from stems and roots of sugarcane

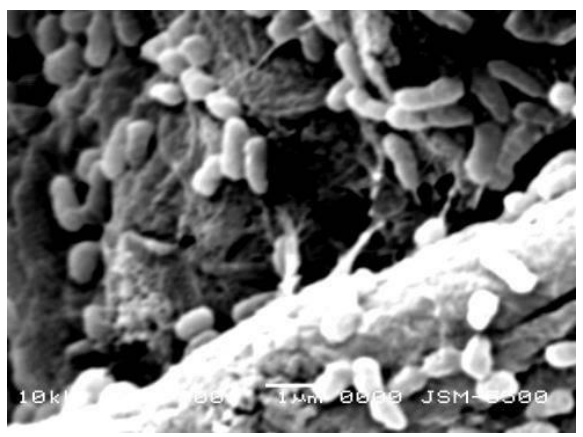

Figure 3. Electron micrographs of cell

\subsection{Screening for Biofertilizer Activities}

Table 2. Nitrogen fixation, phosphate solubilization and IAA synthesis production of 27 isolates

\begin{tabular}{|c|c|c|c|c|c|}
\hline No & Isolate & Site & $\begin{array}{l}\mathrm{NH}_{4} \\
(\mathrm{mg} / \mathrm{L})^{*}\end{array}$ & $\begin{array}{l}\mathrm{P}_{2} \mathrm{O}_{5} \\
(\mathrm{mg} / \mathrm{L})^{* * *}\end{array}$ & $\begin{array}{l}\text { IAA } \\
(\mathrm{mg} / \mathbf{L})^{*}\end{array}$ \\
\hline 01 & LT3b & Stem, Xuanloc & $0.768 \mathrm{e}$ & $24.27 \mathrm{c}$ & $1.702 \mathrm{ab}$ \\
\hline 02 & LT3a & Stem, Xuanloc & $0.191 \mathrm{ij}$ & $10.74 \mathrm{e}$ & $1.801 \mathrm{ab}$ \\
\hline 03 & LT2 & Stem, Trangbom & $0.224 \mathrm{hi}$ & $22.69 \mathrm{c}$ & $1.212 \mathrm{c}$ \\
\hline 04 & LR2 & Root, Trangbom & $0.655 \mathrm{f}$ & $26.31 \mathrm{c}$ & $1.784 \mathrm{ab}$ \\
\hline 05 & LR4 & Root, Trangbom & $0.617 \mathrm{f}$ & $37.60 \mathrm{ab}$ & $1.859 \mathrm{a}$ \\
\hline 06 & LR7 & Root, Dinhquan & 0.714 ef & $41.10 \mathrm{a}$ & $1.718 \mathrm{ab}$ \\
\hline 07 & LT7 & Stem, Dinhquan & $0.879 \mathrm{~d}$ & $32.32 \mathrm{~b}$ & $1.828 \mathrm{ab}$ \\
\hline 08 & LR1a & Root, Trangbom & $0.233 \mathrm{hi}$ & $16.18 \mathrm{~d}$ & $1.844 \mathrm{ab}$ \\
\hline 09 & LT4b & Stem, Trangbom & $0.183 \mathrm{ij}$ & $26.35 \mathrm{c}$ & $1.591 \mathrm{~b}$ \\
\hline 10 & LT4a & Stem, Trangbom & $0.227 \mathrm{hi}$ & $22.86 \mathrm{c}$ & $1.631 \mathrm{ab}$ \\
\hline 11 & LR8b & Root, Dinhquan & $0.626 \mathrm{f}$ & $12.20 \mathrm{e}$ & $1.768 \mathrm{ab}$ \\
\hline 12 & LR6 & Root, Dinhquan & 0.728 ef & $25.08 \mathrm{c}$ & $1.812 \mathrm{ab}$ \\
\hline 13 & LT1 & Stem, Trangbom & $0.671 \mathrm{f}$ & $35.50 \mathrm{~b}$ & $1.636 \mathrm{ab}$ \\
\hline 14 & MB4 & Stem, Dinhquan & $0.104 \mathrm{jk}$ & $01.86 \mathrm{f}$ & $0.401 \mathrm{de}$ \\
\hline 15 & MB7 & Stem, Dinhquan & $0.074 \mathrm{k}$ & $01.24 \mathrm{f}$ & $1.709 a b$ \\
\hline 16 & MR1 & Stem, Dinhquan & $0.117 \mathrm{jk}$ & $00.58 \mathrm{f}$ & $0.374 \mathrm{de}$ \\
\hline 17 & $\mathrm{~T} 16$ & Stem, Trangbom & $1.331 \mathrm{c}$ & $23.16 \mathrm{c}$ & $0.833 \mathrm{~cd}$ \\
\hline 18 & $\mathrm{~T} 12$ & Stem, Vinhcuu & $1.826 \mathrm{~b}$ & $26.21 \mathrm{c}$ & $0.555 \mathrm{~d}$ \\
\hline 19 & $\mathrm{R} 15 \mathrm{~b}$ & Root, Vinhcuu & $2.045 \mathrm{a}$ & $23.08 \mathrm{c}$ & $1.046 \mathrm{c}$ \\
\hline 20 & $\mathrm{R} 16$ & Root, Trangbom & $0.259 \mathrm{hi}$ & $01.46 \mathrm{f}$ & $0.364 \mathrm{de}$ \\
\hline 21 & MR5 & Root, Xuanloc & $0.379 \mathrm{gh}$ & $01.96 \mathrm{f}$ & $1.631 \mathrm{ab}$ \\
\hline 22 & RK4 & Root, Xuanloc & $0.476 \mathrm{~g}$ & $02.05 \mathrm{f}$ & $0.593 \mathrm{~d}$ \\
\hline 23 & MB6 & Root, Xuanloc & $0.296 \mathrm{~h}$ & $00.97 \mathrm{f}$ & $0.427 \mathrm{de}$ \\
\hline 24 & $\mathrm{R} 10$ & Root, Vinhcuu & $0.334 \mathrm{gh}$ & $01.47 \mathrm{f}$ & $0.513 \mathrm{de}$ \\
\hline 25 & $\mathrm{R} 13$ & Root, Vinhcuu & $0.272 \mathrm{hi}$ & $00.99 \mathrm{f}$ & $0.627 \mathrm{~d}$ \\
\hline 26 & MB9 & Root, Dinhquan & $0.312 \mathrm{gh}$ & $01.57 \mathrm{f}$ & $0.286 \mathrm{e}$ \\
\hline 27 & MR4 & Root, Dinhquan & $0.429 \mathrm{~g}$ & $02.01 \mathrm{f}$ & $0.429 \mathrm{de}$ \\
\hline \multirow[t]{3}{*}{28} & & $0.000 \mathrm{k}$ & $00.00 \mathrm{f}$ & $0.000 \mathrm{f}$ \\
\hline & \multicolumn{2}{|c|}{ Calculated F } & $* *$ & & $* *$ \\
\hline & \multicolumn{2}{|l|}{ C.V } & $12.14 \%$ & $15.86 \%$ & $11.47 \%$ \\
\hline
\end{tabular}

Data were recorded at 4 times $(2,4,8,10$ days after inoculation for ammonium and IAA and 5,10,15 and 20 days inoculation for P2O5), the means of 4 replications

Numbers following the same word not difference at $1 \%$ level
Among 27 isolates, 10 isolates having good biofertilizer activity were chosen to study (Table 2). All 10 isolates have nitrogen fixation, phosphate solubilization ability) and all of them produced indole-3-acetic acid (IAA) in vitro. Several isolates have good plant growth activities as LT1, LR2, LR4, LR7, LT7, LR6, T16 (Trangbom), LT7, LR7, LR6 (Dinhquan), LT3 (Xuanloc), and T12, R15b (Vinhcuu)(bold number in Table 2). Endophytes increase plant growth through the improved cycling of nutrients and minerals such as nitrogen, phosphate and other nutrients [30]. Endophytes also promote plant growth by a number of similar mechanisms as phosphate solubilization activity [31][32], indole acetic acid production [33].

\subsection{S rDNA Gene Amplification, Sequencing and Nif-H Gene}

All of them (10 isolates) were chosen to identify and the fragments of $900 \mathrm{bp} 16 \mathrm{~S}$ rRNA were obtained from PCR and sequencing (Table 3), they are endophytic bacteria in sugarcane however all of them are gram-negative bacteria with three groups Alpha-proteobacteria (3 strains), Betaproteobacteria (2 strains) and Gamma-proteobacteria (5 strains).

Table 3. Phylogenetic affiliation of isolates on the basis of $16 \mathrm{~S}$ rDNA genes sequences by using BLAST programme in the GenBank database based on sequence similarity

\begin{tabular}{|c|c|c|}
\hline \multirow{2}{*}{$\begin{array}{l}\text { Taxonomic group and strain } \\
\text { Alphaproteobacteria }\end{array}$} & \multicolumn{2}{|l|}{ Closest species relative } \\
\hline & & \\
\hline LR2 & Sphingomonas sp. PS5 (JX083381) & 99 \\
\hline LR6 & $\begin{array}{l}\text { Novosphingobium sp. ZYY112 } \\
\text { (KJ9400520 }\end{array}$ & 98 \\
\hline LT3b & $\begin{array}{l}\text { Novosphingobium naphthalenivorans } \\
\text { strain VIT-DD2 (KJ716452) }\end{array}$ & 99 \\
\hline \multicolumn{3}{|l|}{ Betaproteobacteria } \\
\hline T16 & $\begin{array}{l}\text { Achromobacter xylosoxidans strain } \\
\text { D32 (KM488475) }\end{array}$ & 98 \\
\hline $\mathrm{R} 15 \mathrm{~b}$ & $\begin{array}{l}\text { Achromobacter insolitus strain zjsru- } \\
11 \text { (KC633947) }\end{array}$ & 99 \\
\hline \multicolumn{3}{|l|}{ Gammaproteobacteria } \\
\hline LT1 & $\begin{array}{l}\text { Klebsiella pneumoniae strain AG4 } \\
\text { (KF758547) }\end{array}$ & 98 \\
\hline LR7 & $\begin{array}{l}\text { Klebsiella variicola strain CICR14 } \\
(\mathrm{KF} 747357)\end{array}$ & 98 \\
\hline LT7 & $\begin{array}{l}\text { Enterobacter oryzae strain } 20 \\
(\mathrm{KC} 843381)\end{array}$ & 99 \\
\hline T12 & $\begin{array}{l}\text { Pantoea agglomerans strain TA22 } \\
\text { (KM269038) }\end{array}$ & 99 \\
\hline LR4 & $\begin{array}{l}\text { Raoultella planticola strain ALK314 } \\
\text { (KC456530) }\end{array}$ & 99 \\
\hline
\end{tabular}

With this level the determination of nearest phylogenetic neighbor sequences for $16 \mathrm{~S}$ rRNA gene sequences of the 10 isolated by the BLAST search program showed that they grouped into two clusters (Figure 4). Cluster A divided two small cluters: cluster A11 with Klebsiella vaniicola LR7, Pantoea agglomerans T12, Klebsiella pneuminiae LT1 have relationship closely and cluster A12 composed of Sphingomonas sp. LR2 and Novosphingobium napthtlalenivorans LT3b. In cluster A2 with 2 strains: Enterobacter oryzae LT7 and Novosphingobium sp. LR6 
were very closely but they orinated from sugar stems in Dinhquan and Trangbom.

Cluster B composed of three strains: Achromobacter insolitus R15b, Raoultella planticola LR4 and Achromobacter xylosoxidans T16 had a relationship closely because they were isolated on site;

The bacterial endophytes has been studied and described as beneficial bacteria which are Gram-negative bacteria (Proteobacteria) [34][35][36] and three strains were classified to Alpha-proteobacteria (30\%), two strains belonged to Betaproteobacteria (20\%) and Gamma-proteobacteria (50\%) composed of five strains (Figure 5) in our result.

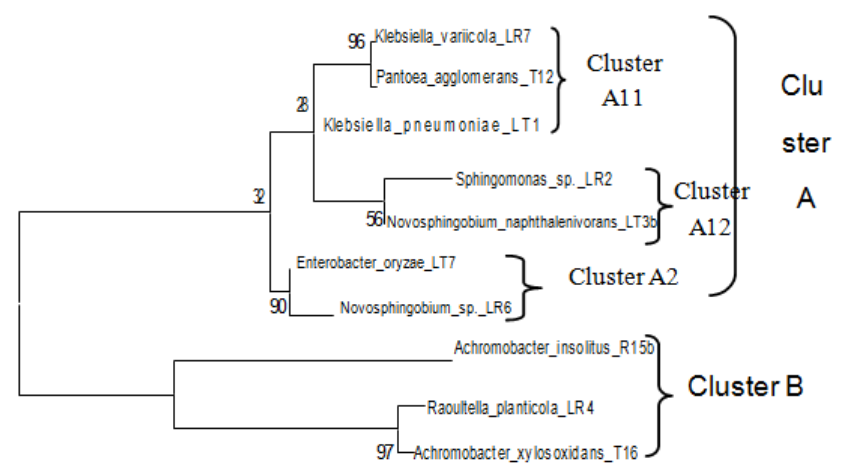

Figure 4. Phylogenetic tree for partial $16 S$ rRNA gene sequences from 10 isolates by using primers (p515FPL, p13B) showing relationships between representative strains along with related sequences retrieved from GenBank. The numbers at the nods indicate the levels of bootstrap support (\%) based on a Maximum-Likelihood analysis of 100 re-sampled datasets. The scale bar indicates the phulogenetic distance sorresponding to 5 changes per 100 bases.

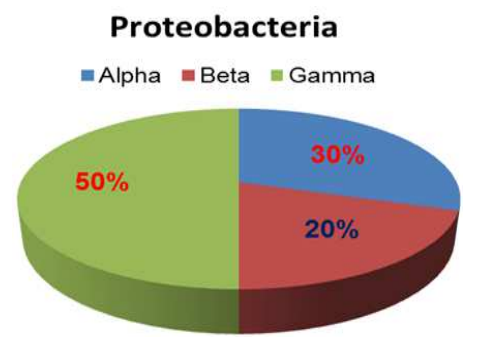

Figure 5. The proportion of group and they distributed in three clusters

Nucleotide polymorphism can be measured by many parameters, such as halotypes (genes) diversity, nucleotide diversity, (Pi), Theta $(\Theta)($ per group) etc... In this study, nucleotide diversity was estimated by Theta $(\Theta)$, the number of segregating sites [37], and its standard deviation (SO). These parameters were estimated by DNA Sequence Polymorphism software version 4.0 [38]. Pi values explained nucleotide diversity of sequences for each gene, the higher values, the more diversity among groups. Gammaproteobacteria group had the highest values. Theta values (per sequence) from S of SNP for DNA polymorphism were calculated for each group, and Gamma-proteobacteria group had the highest values as comparison with Alpha and Betaproteobacteria group (Table 4).
Table 4. Genetic diversity of 10 strains

\begin{tabular}{llll}
\hline & $\begin{array}{l}\text { Nucleotide } \\
\text { diversity }\end{array}$ & $\begin{array}{l}\text { Theta (per site) } \\
\text { from Eta }\end{array}$ & $\begin{array}{l}\text { Theta (per site) } \\
\text { from } \mathbf{S}(\boldsymbol{\theta})\end{array}$ \\
\hline 10 strains & 0.73577 & $0.955 \pm 0.141$ & $0.353 \pm 0.012$ \\
\hline
\end{tabular}

Primer p515FPL 5'-GTGCCAGCAGCCGCGTAA-3' Primer p13B 5'-AGGCCCGGGAACGTATTCAC-3'

In sugarcane, most of the research on endophytic bacteria has focused on diazotrophs, of which the main representatives are Gluconacetobacter diazotrophicus, Herbaspirillum spp. [39][5] and Azospirillum amazonense [40]. However, the presence of diazotroph among the total of bacteria in sugarcane tissues seems to be low in Indian sugarcane [41]. Magnani et al. [42] discovered 32 endophytic bacterial isolates in Brazilian sugarcane (stem and leaf tissues) and 14 strains were classified as the Enterobacteriaceae (Gamma-proteobacteria), among which were Enterobacter (9 strains), Pantoea (3 strains), Kluyvera (1 strain) and Klebsiella (1 strain), based on $16 \mathrm{~S}$ rRNA sequences. Members of the Enterobactericeae family (Gamma-proteobacteria) are frequntly described as rhizosphere colonizers of sugarcane and other grasses [43]. This class includes Enterobacter cloacae and Pantoea agglomerans (formerly Erwinia herbicola)[44]. Many studies have reported the endophytic presence of Enterobacteriaceae members in various crop species [45]. Our results showed that 10 endophytic bacterial strains in sugarcane cultivating on latosols and acrisols of two sites (Dinhquan and Trangbom), Dong Nai province, the southeast of Vietnam belonged to Proteobacteria (gram-negative bacteria) with $50 \%$ strains are Gammaproteobacteria among two strains, Enterobacter oryzae LT7 and Pantoea agglomerans T12, and P. agglomerans has been described to be an important corn and wheat endophyte [46], and it has also been isolated from potato stems [47], rice seeds [48] and citrus leaves [49]. Many studies have shown the potential of Pantoea spp. For systemetic resistance induction [50] and protection against pests and plant-pathogenic microorganisms [51]. Additionally, these bacteria may induce plant growth by increasing the nitrogen supply in nonsymbiotic associations [52], solubilizing phosphorus [53] and stimulating phytohrmone production [54] and recent result of Quecine et al. [55] applied Pantoea agglomerans 33.1 as sugarcane growth promotion successfully. Besides that, Jha and Kumar [56] also identified a novel plant growth promoting endophytic bacterium Achromobacter xylosoxidans from wheat plant and our results also discovered Achromobacter xylosoxidans T16 having good characteristics as high nitrogen fixation, phosphate solubilization and IAA biosynthesis.

Based on bio-safety and good characteristics, this study selected 4 strains as Enterobacter oryzae LT7, Achromobacter xylosoxidans T16, Achromobacter insolitus R15b and Pantoea agglomerans $\mathrm{T} 12$ to evaluate their effects on suganrcane cultivated on acrisols in pot-experiment and the field trial.

\section{Conclusion}

From 14 field-grown sugarcane samples on latosol and acrisols in 4 districts of Dong nai province of the Eastern of 
the South Vietnam, 27 isolates were isolated and identified as sugarcane endophytes, 10 isolates having good plant growth promotion from 4 sites were chosen to analyse their relationship. The results showed that bacterial diversity was very high. 4/10 strains will be suggested to produce biofertilizer for sugarcane cultivation on Acrisols in the future.

\section{Acknowledgements}

The authors thank the helpness of Microbiology BSc. Students and technicians in the Environment Microbiology Laboratory, Biotechnology R\&D Institute, Can Tho University, Vietnam; especially Associate Professor Dr. TRUONG TRONG NGON, Head of Molecular Biotechnology Department, Biotechnology R\&D Institute, Can Tho University, Vietnam for analysing molecular data.

\section{References}

[1] N. Thaweenut, Y. Hachisuka, S. Ando, S. Yanagisawa and T. Yoneyama, "Two season' study on nifH gene expression and nitrogen fixation by diazotrophic endophytes in sugarcane (Saccharum spp. hybrids): expression of nifH genes similar to those of rhizobia," Plant Soil, vol. 338, pp. 435-449, 2011.

[2] J. Dobereiner, "Biological nitrogen fixation in the tropics: social and economic contributions," Soil Biol. Biochem,., vol. 29, pp.771-774, 1997.

[3] J.L. Baldani, V.M. Reis, V.L.D. Baldani and J. Dobereiner, "A brief story of nitrogen fixation in sugarcane - reasons for success in Brasil," Funct. Plant. Biol., vol.29, pp.417-423, 2002.

[4] R.M. Boddey, S. Urguillar, B.J.R. Reis, and V. Reis,"Endophytic nitrogen fixation in sugarcane: present knowledge and future applications," Plant Soil., vol. 252, pp: 139-149, 2003.

[5] V.A. Cavalcante and J. Dobereiner, "A new acid tolerant nitrogen fixing bacterium associated with sugarcane," Plant Soil, vol. 108, pp.23-31, 1988.

[6] F.L.Olivares, E.K.James, J.I.Baldani and J. Dobereiner,"Infection of molted stripe disease susceptible and resistant varieties of sugarcane by the endophytic diazotroph Herbaspirillum, New Phytologist., vol. 135, pp.723-737, 1997.

[7] F.G. Loiret, E. Ortega, D. Kleiner, P. Ortega-rodes, R. Rodes, and Z. Dong, "A putative new endophytic nitrogen-fixing bacterium Pantoea sp. from sugarcane," J. Appl. Microbiol., vol.97, pp.504-511, 2004.

[8] V.M. Reis, S.P. Estrada-de Los Santos, S. Tenorio-Salgodo, J. Vogel, M. Stoffels, S. Guyon, P. Mavigui, V.L. Baldani, M. Schmid, J.I. Baldani, J. Balandreau, A. Hartmann and J. Caballero-Mellado," Burkholderia tropica sp. nov., a novel nitrogen-fixing, plant-associated bacterium,” Int. J. Syst. Evol. Microbiol., vol. 54, pp:2155-2162, 2004.

[9] J. Callero-Mellado, L. Martinez-Aguillar, G. Paredes-Valdes, and P. Estrada-de Los Santos,"Burkholderia unamae sp. nov., and N2-fixing rhizopheric and endophytic species," Int. J. Syst. Evol. Microbiol., vol. 54, pp:1165-1172, 2004.
[10] L. Perin, L. Martinez-Aguillar, R. Castro-Gonzalez, P. Estrada-de Los Santos, T. Cabellos-Avelar, H.V. Guedes, V.M. Reis, J. Caballero-Mellado,"Diazotrophic Burkholderia species associated with field-grown maize and sugarcane," Appl. Environ. Microbiol., vol. 72, pp:3103-3110, 2006.

[11] M. Rosenblueth and E. Martínez-Romero, "Bacterial endophytes and their interactions with hosts," Molecular Plant-Microbe Interactions., vol. 19, pp.827-837,2006.

[12] P. Gyaneshwar, E.K. James, N. Mathan, P.M. Reddy, B. Reinhold-Hurek and J.K. Ladha,"Endophytic colonization of rice by a diazotrophic strain of Serratia marcescens," J. Bacteriol., vol.183, pp: 2634-2645, 2001.

[13] N. Weyens, D. van der Lelie, T. Artois, K. Smeets, S. Taghavi, L. Newman, R. Carleer, J. Vangrontsveld,"Bioaugmentation with engineered endophytic bacteria improves contaminant fate in phytoremediation," Environ. Sci. Technol., vol. 43, pp: 9413-9418, 2009.

[14] L.H. Ba, "Vietnam Soil Resource," Education Publishing House, Vietnam, 2009.

[15] L.H.A. Thi, "Sugarcane Report 2012," (Vietnamese). Ministry of Agriculture and Rural Development Vietanam, January, 2013.

[16] N. Tejera, C. Lluch, M.V. Martinez-Toledo and J. GonzalezLopez,'Isolation and characterization of Azotobacter and Azospirillum strains from the sugarcane rhizosphere," Plant Soil., vol. 270, pp:223-232, 2005.

[17] A. Oak, "A reevaluation of nitrogen assimilation in roots,"BioSci., vol. 42, pp.103-111, 1992.

[18] C. Taule, C. Mareque, C. Barlocco, F. Hackembruch, V.M. Reis, M. Sicardi and F. Battistoni,"The contribution of nitrogen fixation to sugarcane (Saccharum officinarum L.), and the identification and characterization of part of the associated diazotrophic bacterial commnunity," Plant Soil., vol. 356, pp:35-46, 2012.

[19] M. Park, C. Kim, J. Yang, H. Lee, W. Shin, S. Kim and T. Sa, "Isolation and characterization of diazotrophic growth promoting bacteria from Gram rhizosphere of agricultural crops of Korea," Microbiological Research, vol 160, pp. 127133, 2005.

[20] C.S. Nautiyal, "An efficient microbiological growth medium for screening phosphate-solubilizing microorganisms," FEMS Microbiology Letters, vol. 170, pp.256-270, 1999.

[21] S.A. Gordon and R.P. Weber., "Colometric estimation of indolacetic acid,” Plant Physiol., vol 26, pp.192-195, 1951.

[22] B. Neumann, A. Pospiech, and H.U. Schairrer, "Rapid isolation of genomic DNA from Gram-negative," Trends Gent., vol. 8, pp. 332-333, 1992.

[23] D.A. Relman, T.M. Schmidt, E.P. MacDermontt, and S. Falkow, "Identification of the uncultured bacillus of Whipple's disease," N. Engl. J. Med., vol. 327, pp.293-301, 1992.

[24] D.A. Relman, J.S. Loutit, T.M. Schmidt, S. Falkow, and L.S. Tompkin, "The agent of bacillary angiomatosis. An approach to the identification of uncultuted pathogens," N. Engl. J. Med., vol.323, pp.1573-1580, 1990. 
[25] K.D. Zinniel, P. Lambercht, N.B. Harris, Z. Feng, D. Kuczmarshki, P. Higley, C.A. Ishimaru, A. Arunakumari, R.G. Barletta, and A.K. Vidaver, "Isolation and charcaterization of endophytic bacteria from agronomic crops and prairie plants," Appl. Environ. Microbiol., vol. 68, pp. 2198-2208, 2002.

[26] K. Tamura, D. Peterson, N. Peterson, G. Stecher, M. Nei, and S. Kumar, "MEGA5: Molecular Evolutionary Genetics Analysis using Maximum Likehood, Evolutionary Distance and Maximum Parsimony Methods," Mol. Biol. Evol., vol. 28, pp. 2731-2739,2011.

[27] M.K. Halushka, J.B. Fan, K. Bentley, L. Hsie, N. Shen, A. Weder, R. Cooper, R. Lipshutz, and A. Charavarti, "Patterns of single-nucleotide polymorphisms in candidate genes for blood-pressure homestasis," Nat. Genet., vol. 22(3), pp. 239247,1999 .

[28] O.B. Weber, V.L.D. Baldani, K.R.S. Teixeira, G. Kirchof, J.I. Baldani, and J. Dobereiner, "Isolation and characterization of diazotrophic bacteria from banana and pineapple plants," Plant and Soil., vol 210, pp. 103-113, 1999.

[29] N.T.Thu Ha, H.T. Toan, C.N.Điep, "Isolation anf characrterization of endophytic bacteria in several forage grass cultivars," J. Biotechnology., vol. 7(2), pp.241-250, 2009.

[30] R.P. Ryan, K. Germanie, A. Franks, D. J. Ryan and D.N. Dowling, "Bacterial endophytes: recent developments and applications," FEMS Microbiol. Lett., vol. 278, pp.1-9, 2008.

[31] S.C. Verma, J.K. Ladha and A.K. Tripathi, "Evaluation of plant growth promoting and colonization ability of endophytic diazotrophs from deep water rice," J. Biotechnol., vol. 91, pp.127-141, 2001.

[32] S, Wakelin, R. Warren, P. Harvey and M. Ryder, "Phosphate solubilization by Penicillium spp. closely associated with wheat roots," Bio. Fert. Soils, vol. 40, pp.36-43, 2004.

[33] S. Lee, M. Flores-Encarnation, M. Contreras-Zentella, L. Garcia-Flores, J.E. Escamilla and C. Kennedy, "Indole-3acetic acid biosynthesis is deficient in Gluconacetobacter diazotrophicus strains with mutations in cychrome $\mathrm{C}$ biogenesis genes," J. Bacteriol., vol. 186, pp.5384-5391, 2004.

[34] D.Y. Kobayashi, and J.D. Palumbo, "Bacterial Endophytes and Their Effects on Plants and Uses in Agricultulture," C.W. Bacon and J.F. White. Eds, Marcel Dekker, New York, 2000.

[35] C. Lodewyckx, J. Vangronsveld, F. Porteous, E.R.B. Moore, S Taghavi, M. Mezgeay and D. van der Lelie, "Endophytic Bacteria and Their Potential Applications," Critical Reviews in Plant Sciences, vol. 21 (6), pp. 583-602, 2002.

[36] A. Montanez, A.R. Blanco, C.Barlocco, M. Beracochea, and M. Sicardi, "Characterization of cultivable putative endophytic plant growth promoting bacteria associated with maize cultivars (Zea mays L.) and their inoculation effects in vitro," Applied Soil Ecology, vol.58, pp.21-28, 2012.

[37] G.A. Watterson, "On the number of segregation sites in general models without recobination," Theor. Pop. Biol., vol. 7, pp.256-276, 1975.

[38] J. Rozas, and R. Rozas, "DnaSP version 4.1: an integrated program for molecular population genetics and molecular evolution analysis," Bioinformatics, vol. 15, pp. 174-175, 2005.

[39] J.I. Baldani, V.L.D. Baldani, L. Seldin and J.
Dobereiner,"Characterization of Herbaspirillum seropedicae gen. nov. sp. nov., a root-associated nitrogen-fixing bacterium," Int. J. Syst. Bacteriol., vol. 36, pp: 86-93, 1986.

[40] F.B. Reis Junior, L.G. Silva, V.M. Reis and J. Dobereiner,"Occurrence of diazotrophic bacteria in different sugarcane genetypes," Pesp. Agropec. Bras., vol. 35, pp:985994,2000

[41] A.Suman, A.K. Shasany, M. Singh and H.N. Shani,"Molecular assessment of diversity among endophytic diazotrophs isolated from subtropical Indian sugarcane," World J. Microbiol. Biotechnol,, vol.17, pp:39-45, 2001.

[42] G.S.Magnani, C.M. Didonet, L.M.Cruz, C.F.Picheth, F.O.Pedrosa, and E.M.,"Diversity of endophytic bacteria in Brazilian sugarcane," Genetics and Molecular Research, vol.9(1),pp:250-258, 2010.

[43] K.U.Zakria, T. Ogawa, A. Yamamoto, Y. Saeki and S. Akao,'Influence of inoculation technique on the endophytic colonization of rice by Pantoea sp. isolated from sweet potato and by Enterobacter sp. isolated from sugarcane Muhammad," Soil Sci. Plant. Nutr., vol. 54, pp:224-236, 2008.

[44] R.J. Rennie, J.R. De Freitas, A.P. Ruschel and P.B. Vose, "Isolation and identification of N2-fixing bacteria associated with sugarcane (Saccharum sp.," Can. J. Microbiol., vol. 28, pp:462-467, 1982.

[45] A.B. Torres, et al.,"Diversity of endophytic enterobacteria associated with different host plants," J. Microbiol., vol. 46, pp:373-379, 2008.

[46] M. Rossignol, A. Basset, O. Espeli, and F. Bocard, "NKBOR, a miniTn-10-based transposon for random insertion in the chromosome of Gram-negative bacteria and the rapid recovery of sequences flanking the insertion sites in Escherichia coli," Res. Microbiol., vol.152, pp:481-485, 2001.

[47] C.A. Asis and C.A. Adachi,"Isolation of endophytic diazotroph Pantoea agglomerans and nondiazotroph Enterobacter asburiae from sweetpotato stem in Japan," Lett. Appl. Microbiol., vol. 38, pp:19-23, 2004.

[48] S. Ruppel, C. Hecht-Buchholz, R. Remus, U. Artmann and R. Schmeizer, "Settlement of the diazotrophic, phytoeffective bacterial strain Pantoea agglomerans on and within winter wheat:an investagation using ELISA and transmission electron microscoly," Plant Soil., vol. 145, pp:261-273, 1992.

[49] W.L. Ararujo, W. Maccheroni, C. Aguilar-Vidoso, P.A.V. Baroso, H.O. Saridakis, and J.L. Azevedo,"Variability and interaction between endophytic bacteria and fungi isolated from leaf tissues of citrus rootstocks," Can. J. Microbiol., vol.47, pp:229-236, 2001.

[50] M. Ongena, et al.,"Systematic induction of phytoalexins in cucumber in response to treatments with fluorescent pseudomonads," Plant Pathol., vol.49, pp:523-530, 2000.

[51] T.F. Hsich, H.C. huang, and R.S.Erickson, "Biological control of bacterial wilt of bean using a bacterial endophyte, Pantoea agglomerans," J. Phytopathol., vol. 153, pp:608-614, 2005.

[52] S.C. Verma, A. Singh, S.P. Chowdhury and A.K. Tripathi, "Endophytic colonization ability of two deep-water rice endophytes, Pantoea sp. and Ochrobactrum sp. using green fluorescent protein reporter," Biotechnol. Lett., vol. 26, pp:425-429, 2004. 
[53] M.A. Malboobi et al.,"Solubilization of organic and inorganic phosphates by three highly efficient soil bacterial isolates," World J. Microbiol., vol. 25, pp:1471-1477, 2009.

[54] W. Zimmer, B. Hundeshagen, and E. Niederau,"Demonstration of the indopyruvate decarboxylase gene homologous in different auxin producing species of the Enterobacteriaceae," Can. J. Microbiol., vol. 40, pp:1072$1076,1994$.
[55] M.C. Quecine, W.L. Araujo, P.B. Rosetto, A. Ferreira, S. Tsui, P.T. Lacava, M. Moudin, J.L. Azevedo, and A.A.PizziraniKleiner,"Sugarcane Growth Promotion by the Endophytic Bacterium Pantoea agglomerans 33.1," Appl. Environ. Microbiol., 78(21), pp:7511-7518, 2012.

[56] P. Jha and A. Kumar,"Characterization of Novel Plant Growth Promoting Endophytic Bacterium Achromobacter xylosoxidans from Wheat Plant," Microb. Ecol., vol. 58, pp:179-188, 2009. 